\title{
Soil seed bank and its importance in the natural regeneration of degraded areas
}

Danielle Melo dos Santos ${ }^{1 *}$; Kleber Andrade da Silva ${ }^{1}$; Josiene Maria Falcão Fraga dos Santos²; Elcida de Lima Araújo ${ }^{3}$

\begin{abstract}
Dry tropical forests have suffered great degradation by anthropic activities, and many were converted to pasture or agricultural areas. Consequently, the soil seed bank characteristics of these areas have been modified, and its necessary a better understanding of the implications for natural regeneration of forests. In this review, the objective was gathering the current knowledge about the influence of human practices on the remaining soil seed bank of dry environments, in order to highlight the implications of forest resilience and dynamics. Bibliographical survey was carried out, from the following keywords: seed bank, semiarid, and dry forest. In summary, studies show that the soil seed bank is strongly affected by anthropogenic actions. In general, the soil bank of agro pastoral areas suffers species loss, and has a lower seed quantity when compared to areas not disturbed by anthropic action. Therefore, understanding the spatial-temporal dynamics of the seed bank in the post-use land is essential to propose strategies for sustainable management, and vegetation conservation, especially considering the predictive scenario of climate change that should increase the severity of droughts and, perhaps, naturally reduce the seed amount that annually replenishes the soil seed stock.
\end{abstract}

Keywords: Biodiversity; Semi-arid; Dry Forests; Conservation.

\footnotetext{
1 Universidade Federal de Pernambuco, Centro Acadêmico de Vitória, Rua do Alto do Reservatório S/n, Bela Vista CEP: 55608-680, Vitória de Santo Antão-PE, Brasil.

2 Universidade Estadual de Alagoas, Campus III, Rod. Eduardo Alves da Silva, Km 3 Graciliano Ramos, Palmeira dos Índios AL, 57604-595

${ }^{3}$ Universidade Federal Rural de Pernambuco, Departamento de biologia, Área de Botânica, Dois Irmãos, 52171-900, RecifePE, Brasil.
}

*Corresponding author. $\mathrm{E}$ E-mail address: danmelo_bio@hotmail.com 


\section{INTRODUCTION}

The soil seed bank has significant importance for population renewal and structuring of plant communities, and its species richness and seed density reflect the mosaic of variations occurring in space, such as microhabitats and time, mainly due to climatic variations (Santos et al. 2013; Silva et al. 2013).

The temporal-space heterogeneity that naturally occurs in the soil seed bank of the forest is amplified in environments that suffer from acute or chronic anthropogenic disturbances. These disturbances are today regarded as a key factor for understanding the processes dynamics allowing the structuring of tropical forests, since many of them have been converted to pasture and agriculture (Albuquerque et al. 2012; Araújo et al. 2014; Santos et al. 2016).

The soil use and the demands of human populations for survival and regional development has significant importance in the seed bank, especially in the dry forests, such as those occurring in northeastern Brazil, which today have an extensive landscape scenario with degraded secondary forests or total absence of these, and the possible occurrence of desertified areas or in the process of desertification, where the seed bank alone does not allow the resilience of forests (Araújo et al. 2007).

Some studies evaluating the natural regeneration potential of anthropized dry forest areas have shown changes in the species composition and structure of the populations (Barbosa 2008; Bezerra 2009; Erfanzadeh et al. 2014). Anthropic disturbances can lead to a reduction in the diversity and quantity of seeds that annually reach the soil. Therefore, the remaining seed bank would allow a natural regeneration contemplated by a reduced set of species
(Santos et al. 2016), which would result in less diverse secondary forests.

Disturbances intensity and frequency are factors that alter the characteristics of the seed bank, because the increase of perturbation level cause a decrease in the seed density and species richness of the soil bank (Kassahun et al. 2009), reducing the similarity between the seed bank and the local vegetation cover (Chaideftou et al. 2009). In addition, the role of the seed bank in the natural forest regeneration also depends on seed dormancy (Chaideftou et al. 2009; Liu et al. 2009), which interfered with recruitment rates in time and space.

Thus, based on the evidence that the remaining seed bank in the soil assists in the natural regeneration of disturbed areas, this review aims to demonstrate the current state of knowledge about the influence of anthropogenic actions on remaining seed bank in dried environments around the world.

For the development of this review, we used as main criterion to evaluate the knowledge about the effect of the man action on the remaining seed bank in the soil, as well as, to evaluate the potential of this ecological process in the natural regeneration of degraded areas in dry environments.

It is worth mentioning that for the development of this review, the ecosystems considered as dry environment have the following characteristics: 1) the annual average temperature is higher than $17^{\circ} \mathrm{C}$, with an annual rainfall variation between 250 and $1200 \mathrm{~mm}$, and 2) these environments also occur in tropical regions with several months of severe drought, receiving less than $100 \mathrm{~mm}$ of rain for about five or six months of the year. These dry environments received different names and regional classifications. In the northeast region of 
Brazil, the vegetation of the caatinga is very representative of this type of environment (Bezerra 2009), and the different caatinga phytophysiognomies were considered (Araújo et al. 2007).

The bibliographical survey consisted in the search for scientific articles, dissertations, theses, books, and book chapters with the following keywords in Portuguese language: seed bank, semi-arid, and dry forest. Later, these same words were used in English and Spanish, in order to increase the chances of finding works that had not yet been reached.

In this short review, the works carried out between 1997 and 2016 were considered. The search for periodicals available on the Internet was done through the following databases: Biological Abstracts, Scirus, Scielo, Web of Science, Scopus, and Google Scholar. In addition, some publications were requested by contacting authors via e-mail. We intend to present an overview of the concept and dynamics of the seed bank, taking into account the effect of anthropogenic actions.

\section{Seed bank}

Soil seed bank is one of the ecological components shaping the dynamics of an ecosystem. The soil bank may consist of two types of seeds: allochthons (originating from other places) and/or autochthonous (seeds from local species). Seed accumulation in the bank varies according to the entrance (seed dispersal) and exit (germination and death) of the seeds (Baker 1989; Roberts and Simpson 1989; Santos et al. 2013,2016; Silva et al. 2013). Stored seeds in the soil bank can germinate at the moment of dispersion, or remain dormant for longer periods, and they are important for the renewal of adult plants (Mamede and Araújo
2008; Loydi et al. 2012; Santos et al. 2016; Zhang et al. 2013). The presence of these seeds in the soil is determined by physiological factors (germination, dormancy, and viability), and environmental (precipitation, humidity, temperature, light, and the presence of seed predators and pathogens) (Garwood 1989; Santos et al. 2013,2016).

According to these environmental and physiological factors, it is possible to describe two behaviors for the seeds in the bank, in the transient exists the predominance of large seeds, with short life, without dormancy, high recruitment of seedlings, but high mortality rate, and they germinate within a year, after the beginning of the dispersion. Or the persistent, associated to compact, smooth, small seeds, that require special conditions to germinate, thus being dormant and remaining viable in the soil for more than one year (Garwood 1989; Santos et al. 2013, 2016; Silva et al. 2013; Thompson e Grime 1979).

It is possible to assert that not only the environmental and physiological factors will determine the type and size of the soil seed bank, but also specific vegetation characteristics where this seed bank is stored, as well as, the human action in these areas.

\section{Seed bank of anthropogenic areas in the process of natural regeneration}

Disturbances consequences in dry environments around the world have stimulated studies in these areas trying to develop models of regeneration and thus avoid the biodiversity loss of these habitats (Dreber et al. 2011; Santos et al. 2016; Zhang et al. 2013). Studies on soil seed bank with this subject have shown that among the anthropic disturbances two types 
have been studied with more emphasis: pasture and grain cultivation.

In areas of dry forests around the world impacted by pasture the seed bank is generally compromised, occurring species loss and resulting in a lower seed amount when compared to areas that have not undergone any type of anthropogenic action (Chaideftou et al. 2009; Cox and Allen 2008; Dreber et al. 2011; Kassahun et al. 2009; Liu et al. 2009; Loydi et al. 2012; Tessema et al. 2012). According to the authors, in the areas converted to pasture, the floristic similarity of the seed bank is different when compared to the soil bank of native areas (Chaideftou et al. 2009; Cox and Allen 2008). With the reduction of the seed number and the diversity of species of the bank, the natural regeneration of these areas can be affected (Dreber et al., 2011; Loydi et al., 2012; Tessema et al. 2012). For example, Buisson et al. (2006) found that in a dry forest in France, the role of the seed bank in the restoration of abandoned fields after anthropic disturbance was minimal. In addition, in a dry Forest in Namibia, Dreber et al. (2011) observed that perennial species do not have a representative seed bank because of cattle pasture.

Thus, it is possible to consider that the use of the seed bank for natural regeneration of disturbed dry areas will heavily depend on seed dormancy for future recruitment after a disturbance (Kassahun et al. 2009; Liu et al. 2009).

On the other hand, some studies have pointed out that in dry forest areas where intense pastures occur, species richness and seed density in the soil bank are quantitatively larger when compared to areas that have never suffered this type of disturbance (Wang et al. 2009; Wassiea and Teketay 2006). In these works, the authors report that, despite the significant amount of species and seeds in disturbed areas, the soil seed bank of these areas is possibly transient and superficial (Wang et al. 2009). This results from the rotation and the perturbation rate, and, in addition, most of the seeds are of exotic species and/or weed, making unfeasible to use this seed bank for the natural regeneration of these areas (Wassiea and Teketay 2006).

In addition to pasture practices, other forms of dry forests degradation are the agricultural practices. Most of the studies emphasize that such practices contribute to a greater number of species, mainly herbaceous ruderais and / or weeds (Augusto et al. 2001; Teketay 1997). The authors report that the greatest quantity of weed seeds in areas that have suffered some disturbance is due to the fact that: 1) the disturbance promotes the disappearance of native species with low settlement capacity (Augusto et al. 2001); or 2) that previous communities anthropic practices, have not contributed to the formation of the remaining seed bank in the soil (Teketay 1997). It is worth mentioning that the emergence of weed species in disturbed areas will depend on the time and intensity of the disturbance.

Besides, the complete removal of forest spots near these areas makes impossible the natural regeneration of dry forest areas that were converted into permanent crop and later abandoned. For example, Senbeta and Teketay (2002) analyzed the seed bank in a dry forest area in Ethiopia, and found the same result five years prior to this study, demonstrating that in certain areas a longer period of time is required for complete regeneration occur. Therefore, the investigation of the seed bank role in areas anthropized by long time series is a gap that needs to be filled, so that parallels can be drawn between preserved and anthropized 
areas and thus describe the different establishments of the plant community between these sites. Fact confirmed by Zhang et al. (2013), who verified that the species richness and seed density of the soil bank were higher in the dry forests with a longer time of natural regeneration.

In the dry forests of the Brazilian caatinga, some works have proposed to understand how the seed bank can help in the regeneration of the anthropic areas (Barbosa 2008; Bezerra 2009; Mamede and Araújo 2008; Mendes et al. 2015; Santos et al. 2016). For example, in a caatinga area that underwent a burning regime, it was observed an $80 \%$ reduction in seed density and a significant reduction in species diversity (Mamede and Araújo 2008). The authors report that traditional farming practices, such as fires, have a major impact on the soil seed bank, posing a serious threat to the conservation of native caatinga species. On the other hand, there are studies reporting that some anthropic practices, such as native pastures, do not compromise vegetation diversity or floristic composition (Bezerra 2009). In addition, it was also observed that certain caatinga native species have a persistent seed bank (Barbosa 2008) that can assist in the renewal of native plant populations.

Mendes et al. (2015) evaluated the seed bank of a caatinga area that was cut off for palm plantation, and it was abandoned six months later. After 17 years of natural regeneration, the species found in the soil bank were native to caatinga areas and curiously the number of seeds was significantly higher when compared to areas that did not suffer any type of anthropic activity. Later, Santos et al. (2016) analyzed the seed bank of the same area studied by Mendes et al. (2015), and compared to an area that did not undergo any type of anthropic activity during four consecutive years. The anthropic and non-anthropic areas compared by Santos et al. (2016) were separated only by a road of about three meters. After four years of study, it was possible to verify that both the number of species and the number of seeds were significantly higher in the not disturbed vegetation. In addition, the floristic composition differed between areas. The authors confirmed that anthropic actions cause changes in floristic composition, species richness, and soil seed bank density. In addition, it was also possible to verify that interannual precipitation variations can explain $21 \%$ of the species richness and $16 \%$ of the soil seed density (Silva et al. 2013). Microhabitat type also influences the seed richness and density, explaining $7 \%$ of the richness and $31 \%$ of the seed density from mature forests of the caatinga vegetation (Santos et al. 2013).

In summary, the findings on the soil seed bank allow inferring that it is affected by the anthropic actions, consequently, altering the regeneration potential of vegetation. Therefore, seed bank studies are of utmost importance for understanding the forest resilience. Considering the mosaic of temporal space variations of forests and the resulting changes from anthropic activities, as well as, considering the predictions of increasing drought severity and of demands from human populations, this review indicates that the number of studies in this area need to be expanded, so that seed bank dynamics patterns can be evidenced and correlated with other ecological processes of dry forests related to their natural regeneration and conservation of biodiversity. 


\section{ACKNOWLEDGEMENTS}

The authors are grateful to CAPES, CNPq, and FACEPE (DCR -0015-2.05/16; $A P Q-1318-2.05 / 15)$ for the financial support and scholarships.

\section{REFERENCES}

Albuquerque UP, Araújo EL, El-Deir AC, Lima ALA, Souto A, Bezerra BM, Ferraz EMN, Freire EMX, Sampaio EVSB, Las-Casas FMG, Moura GJB, Pereira GA, Melo JG, Ramos MA, Rodal MJN, Schiel N, Lyra-Neves RM, Alves RRN, Azevedo-Júnior SM, Telino Júnior WR, Severi W. (2012) Caatinga revisited: ecology and conservation of an important seasonal dry forest. The Scientific World Journal, 1: 1-18.

Araújo EL, Castro CC, Albuquerque UP (2007) Dynamics of Brazilian caatinga - A review concerning the plants, environment and people. Functional Ecosistems and Communities, 1(1):15-28.

Araújo VKR, Santos DM, Santos JMFF, Lima KA, Souza DNN, Araújo EL (2014) Influência do status da floresta e da variação sazonal sobre o banco de sementes no semiárido brasileiro. Gaia Scientia, 8: 136-149.

Augusto L, Dupouey JL, Picard JF, Ranger J (2001) Potential contribution of the seed bank in coniferous plantations to the restoration of native deciduous forest vegetation. Acta Oecologica, 22: 87-98.

Barbosa MF (2008) Estudo do potencial de regeneração natural: Uma análise da Chuva de sementes, do banco de sementes e do estrato regenerante da vegetação ciliar na Bacia hidrográfica do rio taperoá, semi-árido paraibano, Brasil. Tese de Doutorado, Universidade de São Carlos, São Paulo.

Baker HG (1989) Some aspects of the natural history of seed banks. In: Leck MA; Parker TV, Simpson RLAF. (eds.). Ecology of soil seed banks. Academic Press, London, pp. 9-21.

Bezerra MF (2009) Floristica e fitossociologia do banco de sementes do solo e composição bromatológica do estrato herbáceo da Caatinga, no Cariri Paraibano. Dissertação de Mestrado, Universidade Federal da Paraíba, Paraíba.
Buisson E, Dutoit T, Torre F, Römermann C, Poschlod P (2006) The implications of seed rain and seed bank patterns for plant sucession at the edges of abandoned fields in Mediterranean landscapes. Agriculture, Ecosystems \& Environment ,115: 6-14.

Chaideftou E, Thanos CA, Bergneier E, Kallmanis A, Dimopoulos P (2009) Seed bank composition and above-ground vegetation in response to grazing in sub-mediterranean oak forests (NW Greece). Plant Ecology, doi: 10.1007/s11258-008-9548-1.

Cox RD, Allen EB (2008) Composition of soil seed bank in southern California Coastal sage Scrub and adjacent exotic grassland. Plant Ecology, doi: 10.1007/s11258-007-9383-9.

Dreber N, Oldeland J, Gretil MV, Rooyen V (2011) Species, functional groups and community structure in seed banks of the arid Nama Karoo: grazing impacts and implications for rangelands restoration. Agriculture, Ecossystems and Environment, 141: 399-409.

Erfanzadeh R, Shahbazian R, Zali H (2014) Role of plant patches in preserving flora from the soil seed bank in na overgrazed highmountain habitat in Northern Iran. Journal Agronomic Science Technologic, 19: 229-238.

Garwood NC (1989) Tropical soil seed banks In: Leck MA, Parker TV, Simpson RLAF. (eds). Ecology of soil seed banks. Academic Press, London, pp. 149-209.

Kassahun A, Snyman HA, Smit GN (2009) Soil seed bank evaluation along a degradation gradient in arid rangelands of the Somali region, eastern Etiopia. Agriculture, Ecosystems and Environment, doi: https://doi.org/10.1016/j.agee.2008.10.016

Liu M, Jiang G, Yu S, Li Y, Li G (2009) The role of soil seed banks in natural restoration of the degraded Hunshandak sandlands, northern China. Restoration Ecology, doi: 10.1111/j.1526-100X.2008.00366.x.

Loydi A, Zalba SM, Distel RA (2012) Viable seed banks under grazing and enclosure conditions in Montane Mesic grasslands of Argentina. Acta Oecologica, doi: https://doi.org/10.1016/j.actao.2012.05.002. 
Mamede MA, Araújo FS (2008) Effects of slash and burn practices on a soil seed bank of caatinga vegetation in Northeastern Brazil. Journal of Arid Environments, doi: https://doi.org/10.1016/j.jaridenv.2007.07.014.

Mendes BL, Silva KA, Santos DM, Santos JMFF, Albuquerque UP, Araújo, EL (2015) What happens to the soil seed bank 17 years after clear cutting of vegetations? Revista de Biologia Tropical, doi: http://dx.doi.org/10.15517/ rbt.v63i2.14683

Pekas KM, Schupp EW (2013) Influence of aboveground vegetation on seed bank composition and distribution in a Great Basin desert sage brush community. Journal of Arid Environments, doi: https://doi.org/10.1016/j.jaridenv.2012.08.013

Roberts HA, Simpson RL (1989) Seed banks: general concepts and methodological issues. In: Leck MA, Parker TV, Simpson RLA (eds.) Ecology of soil seed banks. Academic Press, London, pp. 3-7.

Santos DM, Santos JMFF, Silva KA, Araújo VKR, Araújo EL (2016) Composition, species richness, and density of the germinable seed bank over 4 years in young and mature forests in Brazilian semiarid regions. Journal of Arid Environments, doi: https://doi.org/10.1016/ j.jaridenv.2016.02.012

Santos DM, Silva KA, Albuquerque UP, Santos, JMFF, Lopes CGR, Araújo EL (2013) Can spatial variation and inter-annual variation in precipitation explain the seed density and species richness of the germinable soil seed bank in a tropical dry forest in north-eastern Brazil? Flora, doi: https://doi.org/10.1016/ j.flora.2013.07.006

Senbeta F, Teketay D (2002) Soil seed banks in plantations and adjacent natural dry Afromontane forests of central and southern Ethiopia. Tropical Ecology, 43(2): 229-242.
Silva KA, Santos DM, Santos JFF, Albuquerque UP, Ferraz EMN, Araújo EL (2013) Spatiotemporal variation in a seed bank of a semiarid region in northeastern Brazil. Acta Oecologica, doi: https://doi.org/10.1016/ j.actao.2012.10.008.

Teketay D (1997). The impact of clearing and conversion of dry Afromontane forests into arable land the composition and density of soil seed banks. Acta Ecologica, 18(5): 557573.

Tessema ZK, Boer WF, Baars RM, Prins HH (2012) Influence of Grazing on Soil Seed Banks Determines the Restoration Potential of Aboveground Vegetation in a Semi-arid Savanna of Ethiopia. Biotropica, doi: 10.1111/j.1744-7429.2011. 00780.x

Thompson K, Grime, JP (1979) Seasonal variation in the seed bank of herbaceous species in ten contrasting habitats. Journal of Ecology, 67: 893-921.

Wang N, Jiao J, Jia Y, Zhang X (2009) Soil seed bank composition and distribution oneroded slopes in the hill-gully Loess Plateau region (China): influence on natural vegetation colonization. Earth Surface Processes and Landforms, doi: 10.1002/esp.2209

Wassiea A, Teketay D (2006) Soil seed banks in church forests of northern Ethiopia: Implications for the conservation of woody plants. Flora doi: https://doi.org/10.1016/ j.flora.2005.04.002

Zhang H, Chu LM (2013) Changes in soil seed bank composition during early succession of rehabilitated quarries. Ecological Engineering, 55: 43-50.

Received: 15 August 2017

Accepted: 20 February 2018

Published: 01 March 2018 